\title{
Contagious ecthyma in three flocks of goats in Jos-south LGA, Plateau State, Nigeria
}

\author{
AJ Adedeji ${ }^{1 *}$, JA Adole ${ }^{1}$, NC Chima ${ }^{2}$, AS Maguda ${ }^{1}$, DY Dyek ${ }^{1}$, AR Jambol ${ }^{2}$, EO \\ Anefu $^{3}$, JJ Shallmizhili ${ }^{4} \&$ PD Luka ${ }^{2}$ \\ Viral Research Division, National Veterinary Research Institute, Vom, Plateau State, Nigeria \\ Biotechnology Division, National Veterinary Research Institute, Vom, Plateau State, Nigeria \\ Central Diagnostic Division, National Veterinary Research Institute, Vom, Plateau State, Nigeria \\ 4. Unity Veterinary Clinic and Surgery, State Lowcost, Jos, Plateau State, Nigeria
}

*Correspondence: Tel.: + 2348033557985; E-mail: yinkadeji@yahoo.com

\begin{abstract}
Copyright: (C) 2018 Adedeji et al. This is an open-access article published under the terms of the Creative Commons Attribution License which permits unrestricted use, distribution, and reproduction in any medium, provided the original author and source are credited.
\end{abstract}

Publication History: Received: 12-04- 2017 Accepted: 16-09-2017

\begin{abstract}
Contagious ecthyma (CE) is a debilitating disease of sheep, goats and other ruminants caused by Orf virus (ORFV). Suspected outbreaks of CE were reported in three flocks of goats in Jos-South, Plateau State, Nigeria with proliferative lesions on the muzzle, oral commissures, perineal area and legs. Scab samples were collected from all the flocks and the affected animals placed on antibiotics. The samples collected were homogenized and the DNA extracted using QIAamp ${ }^{\circledR}$ DNA Mini kit (QIAGEN, Hilden Germany). The extracted DNA was subjected to polymerase chain reaction (PCR) amplifying two gene fragments: A32L and B2L of the ORFV. Two flocks were West African Dwarf (WAD) breed of goats with $100 \%$ morbidity and $100 \%$ mortality recorded, while the third flock was Kano Brown breed with $6.7 \%$ morbidity and no mortality. A32L and B2L fragments of the ORFV genome was amplified by PCR from samples collected from the flocks. Contagious ecthyma was therefore confirmed based on classical clinical presentations and laboratory confirmation by PCR. Amplification of A32L and B2L gene fragments of the ORFV and 100\% mortality in WAD breed of goats is the first report in Nigeria associated with CE. Further studies should be carried out to understand the role of breed, the epidemiology and economic impact of CE in Nigeria for the utilization of an appropriate control strategy.
\end{abstract}

Keywords: A32L gene, B2L gene, Contagious ecthyma, Goat, Orf virus, polymerase chain reaction, Nigeria

\section{Introduction}

Contagious ecthyma (CE), also called orf, is a debilitating and economically important disease of sheep, goats and other ruminants caused by Orf virus (ORFV) (Buttner \& Rziha, 2002). The ORFV is a double stranded DNA virus classified within the genus Parapoxvirus, subfamily Chordopoxvirinae and family Poxviridae (Delhon et al., 2004: Fleming et al., 2015). Contagious ecthyma is distributed worldwide and it is a zoonosis affecting Man (Essbauer et al., 2010; Nandi et al., 2011). Due to the zoonotic nature of $\mathrm{CE}$, it is an occupational hazard to shepherds, veterinarians and farmers (Essbauer et al., 2010). Contagious ecthyma is characterized by proliferative erythematous macule, papule, vesicle, pustule, scab lesions on the lips, the oral mucosa and around the nostrils of affected animals (Buttner \& Rziha, 2002; Scagliarini et al., 2012). Lesions can also be found on the teats of udder in affected animals but rarely on other organs (Nandi et al., 2011). Morbidity associated with CE outbreaks can be up to $100 \%$, 
while mortality rates are usually low, but $20-50 \%$ mortality rates have been reported particularly in secondary complications such as stress, immunosuppression or concomitant infections (Hosamani et al. 2009; Scagliarini et al., 2012).

Despite the fact that CE is reported to be a selflimiting disease, symptomatic treatment with topical dressing and use of local antiseptics is beneficial (Nandi et al., 2011). However, secondary bacterial contamination in CE is common and administration of topical and systemic antibiotics can be used for management of the disease (Nandi et al., 2011). Vaccination coupled with biosecurity measures is an effective method in the prevention and control of CE (Nandi et al., 2011). Suspected CE can be diagnosed based on the characteristic clinical signs, followed by laboratory tests such as electron microscopy, serum neutralization test (SNT), histopathology of affected tissues and nucleic acid assay like polymerase chain reaction (PCR) (Nandi et al., 2011). Polymerase chain reaction is a reliable technique for the diagnosis of CE and can differentiate ORFV from other pox viruses such as sheep pox and goat pox (Kottaridi et al., 2006; Hosamani et al., 2009). The A32L gene fragment is located in the highly conserved region of the ORFV and is capable of encoding an ATPase that mediates virion's DNA packaging (Chan et al., 2009). The $\mathrm{B} 2 \mathrm{~L}$ genes encodes the major envelop protein of the virus and it is a highly immunogenic protein with lipase activity (Chan et al., 2009; Friederichs et al., 2014; Zhang et al., 2014; Gelaye et al., 2016). The A32L and B2L genes are commonly used for molecular characterization and are also suitable for viral strain differentiation of ORFV (Chan et al., 2009, Zhang et al., 2014; Gelaye et al., 2016). Contagious ecthyma was first reported in Nigeria by Obi and Gibbs (1978) and not much is known about the epidemiology of the disease in Nigeria. From the few available reports, there is paucity of information on the mortality pattern from CE outbreaks in Nigeria (Adeoye, 1984; Adedeji et al., 2017). This study describes CE outbreaks in three flocks of goats in JosSouth, Plateau State, Nigeria.

\section{Case Report}

Case history and sample collection

The area is situated approximately on latitude $9^{\circ} 55^{\prime} 42^{\prime \prime} \mathrm{N}$, longitude $8^{\circ} 53^{\prime} 31^{\prime \prime} \mathrm{E}$. Jos lies close to the geographical centre of Nigeria and Plateau State is bordered by Bauchi and Kaduna States to the north and Taraba and Nasarawa States to the south. Between the years 2014 and 2016, three suspected outbreaks of CE were reported in three different flocks of goats in Jos-South, Plateau State, Nigeria. Skin lesions were observed on the ears, lips, teats of the udder, tails and hooves of the affected goats. All the flocks were reared on semi-intensive system of farming. Complete history and clinical signs of the disease observed during examination of the goats were recorded and presented in a table. Scab samples were collected from animals with skin lesions, labeled appropriately and transported on ice to the Viral Research Divison, National Veterinary Research Institute, Vom. The samples were stored at $-20{ }^{\circ} \mathrm{C}$ until used. Long acting oxytetracycline was administered at $20 \mathrm{mg} / \mathrm{kg}$ to all the affected goats in the three flocks alongside topical application of gentian violet on the skin lesions as palliative measure. The study was carried out in Jos-South which is part of Jos, the administrative capital of Plateau State, Nigeria.

\section{Morbidity and mortality rates}

Morbidity and mortality rates of CE in each of the three flocks of goats were calculated based on the number of affected and dead goats with the aid of records obtained from owners of the flocks. The results were presented in percentages and tabulated.

\section{DNA extraction and polymerase chain reaction}

The scab samples were homogenized using sterile mortars and pestles with the aid of sterile sand and physiological buffer saline to produce $20 \%$ tissue suspension. DNA extraction was carried out using QIAamp ${ }^{\circledR}$ DNA Mini kit from (QIAGEN, Germany) following the manufacturer's instructions. ORFV vaccine strain (Orf freeze-dried vaccine, Onderstepoort Biological Products Ltd., Onderstepoort, South Africa) was used as a positive

Table 1: Primer sequences used to amplify the $A 32 \mathrm{~L}$ and $\mathrm{B} 2 \mathrm{~L}$ gene fragments of the orf virus

\begin{tabular}{ccccc}
\hline Gene Target & Primer & Sequences (5'-3') & Size (bps) & Reference \\
\hline Viral ATPase protein & ORFV-A32-F & CTCCATTTAGAGGCCGTGAG & 1098 & Gelaye et al., 2016 \\
ORFV-A32L-R & CGTGTTATGTGCCATCTTGC & & \\
Major envelope protein gene & ORFV-B2L F & GACCTTCCGCGCTTTAATTT & 1210 & Gelaye et al., 2016 \\
& ORFV-B2L R & CCCGCCTGCTAAAAGACT & & \\
\hline
\end{tabular}


control, and thus subjected to DNA extraction and $\mathrm{PCR}$, while an aliquot of molecular grade water was used as the negative control.

Amplification of the full length of $A 32 L$ and B2L gene fragments of ORFV was carried out using primers designed by Gelaye et al. (2016) from ORFV with accession number: NC005336 (Table 1). Amplification of the A32L gene of the ORFV was carried out in $25 \mu \mathrm{l}$ reaction volume consisting of $20 \mathrm{pmol}$ of each primer, $2 \mathrm{mM}$ dNTPs, 1x PCR Buffer (Qiagen), $2.5 \mathrm{U}$ taq polymerase and $5 \mu \mathrm{l}$ of DNA. The cycling conditions were: initial denaturation at $95{ }^{\circ} \mathrm{C}$ for $5 \mathrm{~min}$, followed by 35 cycles at $95{ }^{\circ} \mathrm{C}$ for $50 \mathrm{~s}, 55$ ${ }^{\circ} \mathrm{C}$ for $60 \mathrm{~s}$ and $72^{\circ} \mathrm{C}$ for $90 \mathrm{~s}$, and final extension at $72^{\circ} \mathrm{C}$ for $7 \mathrm{~min}$. The same protocol was used for the B2L gene except that the annealing was done at 52 ${ }^{\circ} \mathrm{C}$ instead of $55{ }^{\circ} \mathrm{C}$ (Gelaye et al., 2016). The PCR amplicons were resolved on $1.5 \%$ agarose in Trisborate- EDTA (TBE) buffer gels stained with $0.5 \mu \mathrm{g} / \mathrm{ml}$ ethidium bromide. Ten microlitres of the PCR product from each of the tubes were mixed with $1 \mu \mathrm{l}$ of $6 \mathrm{X}$ buffer and electrophoresed along with $1 \mathrm{~kb}$ DNA molecular weight marker (New England BioLabs, Inc) at a constant $80 \mathrm{~V}$ for $45 \mathrm{~min}$ in $1 \mathrm{X}$ TBE buffer. Amplified product was viewed under UV light and documented by a UV-transilluminator. The A32L and $\mathrm{B} 2 \mathrm{~L}$ genes of the ORFV amplified gave the expected target band size of 1098bps and 1210bps respectively as positive samples.

\section{Results and Discussion}

In the three flocks of goats studied, the following clinical signs were observed: anorexia, emaciation, proliferative lesions on oral commissures, and the perineal region which are presented in Table 2. Two flocks were West African Dwarf (WAD) breed of goats, while the third flock was Kano brown breed of goats (Table 2). The first outbreak of CE in the first flock of WAD occurred in September 2014 with 100\%
(11/11) morbidity and $100 \%(11 / 11)$ mortality rates. Plates $1 \mathrm{~A}, 1 \mathrm{~B}, 1 \mathrm{C}$ and $1 \mathrm{D}$ show the CE lesions observed in the first flock of goats. The mortality occurred over a period of three weeks, the goats were between 2 weeks and 2 years of age and all ages were affected. The second outbreak of CE in the second flock occurred in May 2016, with only one goat affected initially. The disease subsequently spread to the whole flock with $100 \%(4 / 4)$ mortality (Table 2) despite the palliative treatment administered. Plate $1 \mathrm{E}$ shows one of the affected goats in the second flock. The mortality occurred over a period of four weeks and the goats were between 4 months and 3 years of age. The third outbreak of CE in the third flock occurred in August 2016, the goats were Kano Brown breed (Plate 1F), and $6.7 \%(1 / 15)$ morbidity was recorded with no mortality. The affected goat recovered after supportive treatment was administered. In the third flock there were goats as young as 3 weeks of age, but they did not present clinical signs suggestive of CE (Table 2). All the outbreaks of CE in the three flocks of goats occurred during the raining season.

The scab samples were collected as follows: flock 1 (4), flock 2(2) and flock 3 (1). The samples were positive by PCR through the detection of both the A32L and B2L genes of the ORFV. The PCR amplicons on $1.5 \%(\mathrm{w} / \mathrm{v})$ agar gel electrophoresis showed the amplification of $\mathrm{A} 32 \mathrm{~L}$ and $\mathrm{B} 2 \mathrm{~L}$ gene fragments of the ORFV in the scab samples collected from the flocks of goats. Representative samples of the PCR amplicons were taken from each flock of goats as shown in Figure 1 (A \& B). The A32L and B2L genes of the ORFV were amplified at the expected band size as presented in Figure 1 (A \& B). The positive control was also amplified at the expected band size while the negative control was not amplified. This study reports the outbreak of CE in three flocks of goats which were confirmed by

Table 2: Clinical manifestation of contagious ecthyma in three flocks of goats in Jos-South, Plateau State, Nigeria

\begin{tabular}{|c|c|c|c|c|c|c|c|c|}
\hline Flock & Location & $\begin{array}{l}\text { Year of } \\
\text { Outbreak }\end{array}$ & $\begin{array}{l}\text { Flock } \\
\text { size }\end{array}$ & Breed & Age & Clinical signs & $\begin{array}{l}\text { Morbidity } \\
\text { (\%) }\end{array}$ & $\begin{array}{l}\text { Mortality } \\
(\%)\end{array}$ \\
\hline 1 & $\begin{array}{l}\text { Rantya, } \\
\text { Jos- } \\
\text { South }\end{array}$ & $\begin{array}{l}\text { Sept, } \\
2014\end{array}$ & 11 & $\begin{array}{l}\text { West } \\
\text { Africa } \\
\text { Dwarf }\end{array}$ & $\begin{array}{l}2 \text { weeks } \\
-2 \text { years }\end{array}$ & $\begin{array}{l}\text { Anorexia, proliferative lesion, scabs on } \\
\text { the ears, around the eyes, lips, teats of } \\
\text { the udder, perineal region, and } \\
\text { interdigital space of hooves. Ulcers in the } \\
\text { mouth }\end{array}$ & $\begin{array}{l}100 \% \\
(11 / 11)\end{array}$ & $100 \%(11 / 11)$ \\
\hline 2 & $\begin{array}{l}\text { Kuru, } \\
\text { Jos- } \\
\text { South }\end{array}$ & May, 2016 & 4 & $\begin{array}{l}\text { West } \\
\text { Africa } \\
\text { Dwarf }\end{array}$ & $\begin{array}{l}4 \text { month } \\
-3 \text { years }\end{array}$ & $\begin{array}{l}\text { Proliferative lesions and scabs around the } \\
\text { eye and on the lips. Anorexia and } \\
\text { emaciation. }\end{array}$ & $100 \%(4 / 4)$ & $100 \%(4 / 4)$ \\
\hline 3 & $\begin{array}{l}\text { Kuru, } \\
\text { Jos- } \\
\text { South, }\end{array}$ & $\begin{array}{l}\text { August } \\
, 2016\end{array}$ & 15 & $\begin{array}{l}\text { Kano } \\
\text { Brown }\end{array}$ & $\begin{array}{l}3 \text { weeks } \\
-6 \text { years }\end{array}$ & $\begin{array}{l}\text { Proliferative lesions around the muzzle, } \\
\text { lips, legs and scrotum }\end{array}$ & $6.7 \%(1 / 15)$ & 0 \\
\hline
\end{tabular}



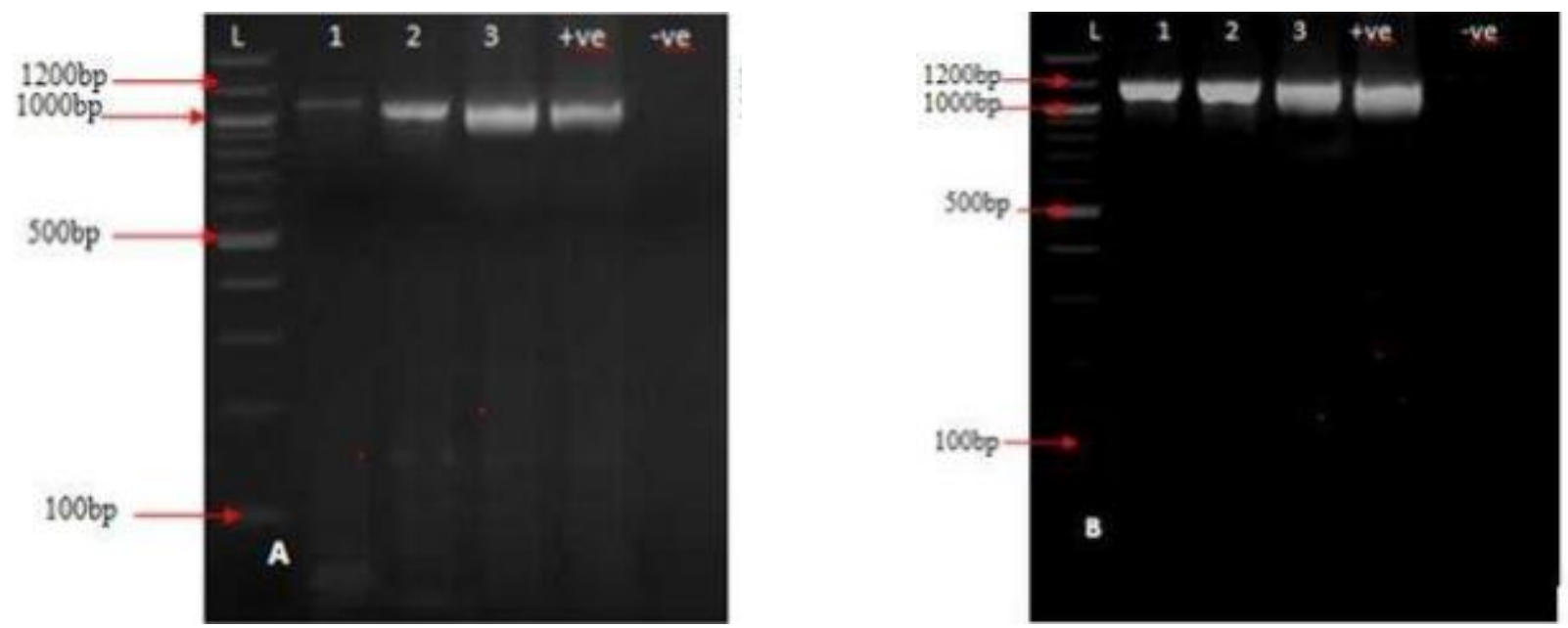

Figure 1- A: Agar gel electrophoresis of polymerase chain reaction product of A32L gene of orf virus. Lanes 1-3 are the representative scab samples from the flocks, positive samples were amplified at $1098 \mathrm{bps}$. + $v$ is the positive control while -ve is the negative control. B: Agar gel electrophoresis of polymerase chain reaction product of B2L gene of orf virus. Lanes 1-3 show the representative scab samples collected from the flocks; positive samples were amplified at 1210 bps. +ve is the positive control while -ve is the negative control
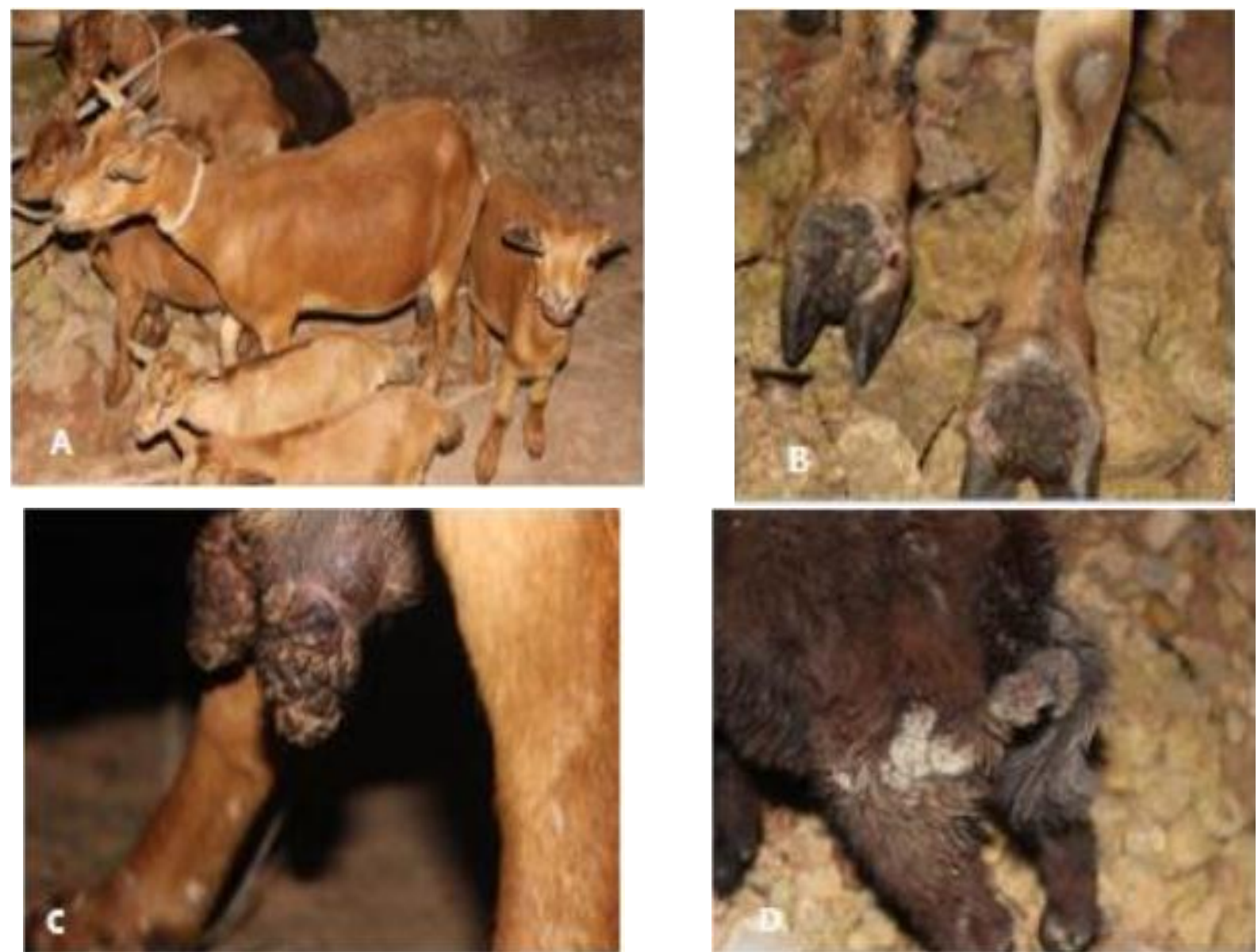

Plate IA-D: A: West African Dwarf goats with lesions of contagious ecthyma from the first flock, scab lesions on the lips of a doe and kids. B: Proliferative lesions of contagious ecthyma between the interdigital space of the hoof of one the goats in the first flock. C: Proliferative lesions on the teat of the udder of doe in the first flock. D: Proliferative lesions of contagious ecthyma on the hind leg of a West African Dwarf goat in the first flock. 

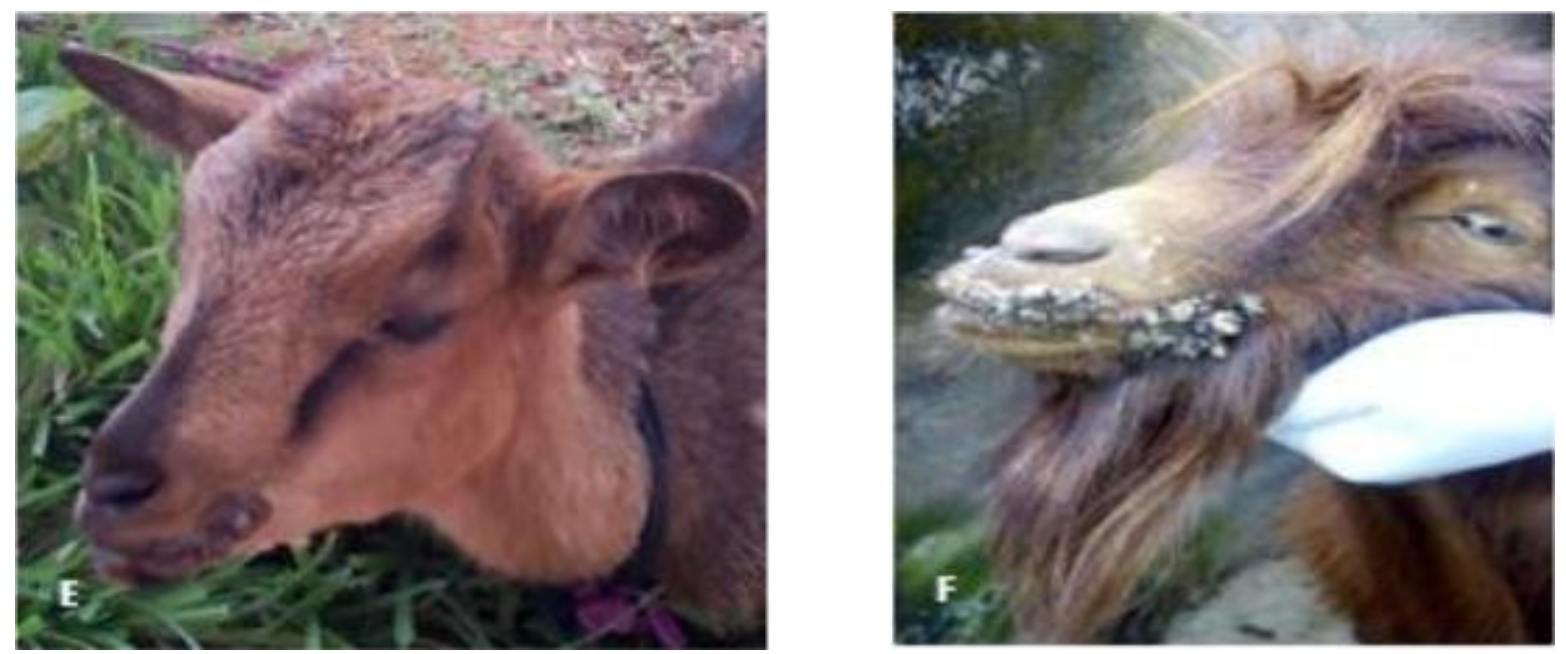

Plate IE-F: E: Scab lesion on the lips of a West African Dwarf goat from the second flock. F: A Kano Brown goat with cauliflower like proliferative lesions of contagious ecthyma on the lips of the only goat affected in the third flock

detection of the ORFV using PCR. Although other laboratory techniques can be used in the diagnosis of CE besides PCR, several reports indicate that PCR is the most reliable technique in the confirmatory diagnosis of CE (Torfason \& Gunadottir, 2002; Kottaridi et al., 2006; Chan et al., 2009; Mahmoud et al., 2010). Clinical signs observed in the three flocks of goats in this study were suggestive of $C E$ and from the samples collected the $A 32 \mathrm{~L}$ and $\mathrm{B} 2 \mathrm{~L}$ genes of the ORFV were amplified by PCR. The detection of the two gene fragments of ORFV by PCR in the samples collected from all the flocks of goats confirms that the outbreak being investigated was CE. Goats are important sources of food and income for rural populace in Nigeria and other developing countries (Hosamani et al. 2009; Adeleye et al., 2016). The 100 $\%$ mortality recorded in two of the flocks suggests that CE is a threat to the livelihood of many in the rural areas if not controlled. Although CE is not among the OIE list of notifiable diseases of livestock possibly because its self-limiting nature, it may be grossly underreported and economic losses underestimated in Nigeria (Adedeji et al., 2017). Our report of $100 \%$ mortality which is higher than previous reports of a low and varying mortality of $2.6 \%-5.4 \%$ by Okoh (1980), Adeoye (1984) and Adedeji et al. (2017) from different parts of the country. This underscores the need for animal health professionals to pay more attention to CE. Comparatively, CE is not as devastating as peste des petits ruminants (PPR), sheep pox and goat pox in small ruminants, nevertheless it has a high impact on the trade value of affected animals due to the debilitating lesions caused by the disease on affected animals (Hosamani et al., 2009; Scagliarini et al.,
2012). High mortality in CE outbreaks is usually reported in young animals and as a result of complication by secondary infections in older animals (Hosamani et al. 2009; Scagliarini et al., 2012). We observed high mortality within the two flocks, albeit the role of age and secondary bacteria was not investigated. Breed-wise, our findings revealed a high mortality rate among WAD goats compared to Kano Brown breed of goats. Earlier, reports of CE in Nigeria by Adeoye (1984) indicated a $2.6 \%$ mortality in Southwest Nigeria, while Adedeji et al. (2017) reported 3.3\% mortality in Uyo, SouthSouth Nigeria, both in WAD breeds of goats. Our finding is suggestive of the fact that WAD goats may be more susceptible to CE than other breeds of goats in Nigeria. Similarly, the epidemiology of PPR has shown that WAD goats are more susceptible than other breeds of goats (Lefèvre \& Diallo, 1990). Although the aim of this study was not to compare susceptibility of breeds to CE, we hypothesized that breed may play a role in the susceptibility and clinical presentation of CE in Nigeria.

In conclusion, contagious ecthyma was confirmed based on classical clinical presentation and laboratory investigation using PCR which detected the $A 32 L$ and $B 2 L$ genes of the ORFV from clinical samples collected. Amplification of $\mathrm{A} 32 \mathrm{~L}$ and $\mathrm{B} 2 \mathrm{~L}$ gene fragments of the ORFV by PCR in this study is the first report in Nigeria. Higher mortalities were observed in WAD goats compared to Kano Brown breeds of goats in Nigeria. We hypothesized that breed and intrinsic genetic factors may be responsible for the clinical presentation of the disease in small ruminants. Therefore, further studies should be carried out to understand breed 
susceptibility, epidemiology and economic impact of CE in Nigeria.

\section{Acknowledgment}

We acknowledge the National Veterinary Research Institute, Vom, where the work was done. We also wish to acknowledge Dr. TM Joannis who assisted us with part of the materials for the Laboratory analysis and Dr. David Lazarus who gave us the positive control.

\section{References}

Adedeji AJ, Maurice NA, Wungak YS, Adole JA, Chima NC, Woma TY, Chukwuedo AA \& Shamaki D (2017). Diagnosis of orf in West African Dwarf goats in Uyo, Akwa Ibom state, Nigeria. African Journal of Infectious Diseases, 11(2): 90-94.

Adeleye O, Alli-Balogun JK, Afiemo OG \& Bako S (2016). Effects of goat production on the livelihood of women in Igabi, Chikun and Kajuru Local Government Areas, Kaduna state, Nigeria. Asian Journal of Agricultural Extension, Economics and Sociology, 11(1): 1-8.

Adeoye SAO (1984). Disease profiles of sheep and goats in two groups of villages in southwest Nigeria. Proceedings of the Workshop on Small Ruminant Production Systems in the Humid Zone of West Africa, Ibadan, Nigeria, Pp $23-26$.

Buttner M \& Rziha HJ (2002). Parapoxviruses: From the lesion to the viral genome. Journal of Veterinary Medicine, 49 (1): 7-16.

Chan KW, Yang CH,Lin JW, Wang HC, Lin FY, Kuo ST, Wong ML \& Hsu WL (2009). Phylogenetic analysis of parapoxviruses and the Cterminal heterogeneity of viral ATPase proteins. Gene, 432(1-2): 44-53.

Delhon G, Tulman ER, Afonso CL, Lu Z, de la ConchaBermejillo A, Lehmkuhl HD, Piccone ME, Kutish GF \& Rock DL (2004). Genomes of the parapoxviruses orf virus and bovine popular stomatitis virus. Journal of Virology, 78(1): 168-177.

Essbauer S, Pfeffer M \& Meyer H (2010). Review Zoonotic poxviruses. Veterinary Microbiology, 140(1): 229-236.

Fleming SB, Wise LM \& Mercer AA (2015) Molecular genetic analysis of orf virus: A poxvirus that has adapted to skin. Viruses, 7(3): 15051539.

Friederichs S, Krebs S, Blum $\mathrm{H}$, Wolf $\mathrm{E}$, Lang $\mathrm{H}$, von Buttlar H \& Büttner M (2014). Comparative and retrospective molecular analysis of parapoxvirus (PPV) isolates. Virus Research, 181: 11-21.

Gelaye E, Achenbach JE, Jenberie S, Ayelet G, Belay A, Yami M, Loitsch A, Grabherr R, Diallo A \& Lamien CE (2016). Molecular characterization of orf virus from sheep and goats in Ethiopia, 2008-2013. Virology Journal, doi: 10.1186/s12985-016-0489-3.

Hosamani M, Scagliarini A, Bhanuprakash V, Mclnnes CJ \& Singh RK (2009). Orf: An update on current research and future perspectives. Expert Review of Anti-infective Therapy, 7(7): 879-893.

Kottaridi C, Nomikou K, Lelli R, Markoulatos P \& Mangana O (2006). Laboratory diagnosis of contagious ecthyma: Comparison of different PCR protocols with virus isolation in cell culture. Journal of Virological Methods, 134(1-2):119-124.

Lefèvre PC \& Diallo $A(1990)$. Peste des petits ruminants. Revue Scientifique et Technique, 9(4): 951-965.

Mahmoud M, Abdelrahman K \& Soliman H (2010). Molecular and virological studies on contagious pustular dermatitis isolates from Egyptian sheep and goats. Research in Veterinary Science, 89(2): 290-294.

Nandi S, Ujjwal KD \& Chowdhury S (2011) Current status of contagious ecthyma or Orf disease in goat and sheep-A global perspective. Small Ruminant Research, 96(1-2): 73-82.

Obi TU \& Gibbs EPJ (1978). Orf on sheep and goats in Nigeria. Tropical Animal Health and Production, 10(1): 233-235.

Okoh AEJ (1980). Contagious ecthyma in exotic sheep in Nigeria. Tropical Animal Health and Production, 12(3): 192.

Scagliarini A, Piovesana S, Turrini F, Savini F, Sithole F \& McCrindle CM (2012). Orf in South Africa: Endemic but neglected. Onderstepoort Journal of Veterinary Research, 79(1): 1-8.

Torfason EG \& Gunadottir S (2002). Polymerase chain reaction for laboratory diagnosis of orf virus infections. Journal of Clinical Virology, 24(2):79-84.

Zhang K, Liu Y, Kong H, Shang Y \& Liu X (2014). Comparison and phylogenetic analysis based on the B2L gene of orf virus from goats and sheep in China during 2009-2011. Archives of Virology, 159(6): 1475-1479. 